\title{
PEMERINTAHAN JOKOWI-JUSUF KALLA MENURUT KACAMATA 5 MEDIA MASSA DI INDONESIA
}

\author{
Theresia D. Wulandari \\ Fakultas Ilmu Sosial dan Ilmu Politik \\ Universitas Atma Jaya Yogyakarta Jalan Babarsari Nomor 6 Yogyakarta 55281, \\ Telp 0274-487711. \\ Email: wulandari@mail.uajy.ac.id
}

\begin{abstract}
Mass media has strong impact to public interest and has formed public perception on issues based on news they published. One of the most popular issues was one year period of Jokowi-Kalla presidential leadership in October 20, 2015. Evaluation, achievement, and reflection of both President and vice president who raise Nawacita program are assumed as indicators of success of them in leading Indonesia. Media objectivity in mass media is the main key in this research because objectivity is very important. The research used quantitative analysis by Robert Entman framing method. It was conducted by text analysis to editorial of five printed media, i.e: Jawa Pos, Kompas, Media Indonesia, Republika, and Tempo, published at October 20, 2015. The research also employs interview and observe secondary sources to as a part of contectual analysis. The result shows objectivity and imparsiality of five printed media in Indonesia in covering Jokowi and Jusuf Kalla presidential leadership. It is shown how media preserve Jokowi-Kalla performance in their 1st year governance as news object.
\end{abstract}

Keywords: objectivity, editorial note, performance, Jokowi-Kalla, framing

\begin{abstract}
Abstrak
Media massa memiliki pengaruh besar dan turut membentuk persepsi publik terhadap isu yang disampaikan melalui berita-beritanya. Salah satu berita yang menarik perhatian adalah kinerja setahun pemerintahan Presiden Joko Widodo dan Wakil Presiden Jusuf Kalla yang jatuh pada 20 Oktober 2015. Evaluasi, capaian, dan refleksi pasangan yang mengusung program Nawacita ini dianggap menjadi indikator keberhasil keduanya dalam memimpin Indonesia. Objektivitas berita di media massa dijadikan sebagai kunci utama dalam penelitian ini, karena obyektifitas berita merupakan satu hal yang penting. Penelitian ini menggunakan penelitian kuantitatif dengan metode analisis framing Robert Entman terhadap teks berita tajuk rencana 5 media massa, yaitu Jawa Pos, Kompas, Media Indonesia, Republika, dan Tempo yang diterbitkan pada 20 Oktober 2015. Analisis lanjutkan dengan wawancara dan atau mencari sumber sekunder sebagai bagian dari kelengkapan analisis konteks. Hasil penelitian ini menemukan objektivitas dan imparsialitas kelima media massa di Indonesia dalam memberitakan kepemimpinan Joko Widodo dan Jusuf Kalla. Penelitian ini juga mengungkap kebijakan redaksi media massa mengawal pemberitaan terkait kinerja Presiden Joko Widodo dan Wakil Presiden Jusuf Kalla dalam periode setahun pemerintahan mereka.
\end{abstract}

Kata kunci: Obyektifitas, tajuk rencana, kinerja, Jokowi-Kalla, framing

\section{Pendahuluan}

Media massa dan opini publik mempunyai hubungan yang sejalan dalam melahirkan isu-isu yang kontroversial, artinya opini publik juga turut dipengaruhi oleh bagaimana media massa mengemas informasi dalam berita. Hal ini seperti disampaikan Ardianto, Komala, dan Karlinah dalam penjelasannya tentang teori Agenda Setting di mana teori menjelaskan adanya hubungan positif antara penilaian yang diberikan media terhadap cara berpikir masyarakat pembacanya. Dengan kata lain, apa yang dianggap penting oleh 
media, akan dianggap penting juga oleh masyarakat (Ardianto, 2009: 77) yang sejalan dengan fungsi media (Sudarman, 2008: 7-8).

Media massa juga digunakan untuk menjangkau khalayak sehingga media massa memiliki peran penting dalam kehidupan bermasyarakat. Termasuk di dalamnya menurut John Locke dalam konteks proses politik, media merupakan pilar keempat dalam demokrasi selain tiga pilar yang lain yaitu eksekutif, legislatif, dan yudikatif (Cangara, 2014: 72).

Berita yang menarik dan mendapat perhatian tentu tidak lepas dari nilai berita yang diangkat oleh media. Termasuk di dalamnya media massa yang memberi pengaruh besar pada isu-isu politik, terutama berita yang melibatkan sosok tokoh (Siregar, 1987: 27). Maka pemberitaan tentang evaluasi pemerintahan Presiden Joko Widodo dan Wakil Presiden Jusuf Kalla yang jatuh pada 20 Oktober 2015 mendapat perhatian khusus bagi media massa di Indonesia. Evaluasi kinerja pemerintahan seakan menjadi tradisi pasca pemerintahan reformasi, sebagai bentuk evaluasi dan tolak ukur kinerja dan keberhasilan agenda kerja penguasa beserta perangkatnya.

Dilihat dari sosoknya, Jokowi dan Jusuf Kalla yang terpilih sebagai presiden dan wakil presiden pada 20 Oktober 2014 dianggap cukup kontroversial. Obyektifitas dan keberimbangan (imparsialitas) menjadi syarat mutlak bagi media massa dalam menciptakan isu yang kemudian dirancang menjadi produk berita. Maggie Gallagher dalam Khairani (2012: 17) mengatakan bahwa prinsip utama seorang jurnalis dalam menciptakan produk beritanya bukan hanya netralitasnya saja (obyektifitas), namun juga independensinya. Demikian juga yang disampaikan lewat Kovach dan Rosentiel (2004: 119-121), semakin wartawan melihat dirinya sebagai bagian dari peristiwa, loyal pada narasumber, maka dia akan semakin sulit menganggap dirinya wartawan. Ini dikatakan oleh Gallagher sebagai hubungan antara jurnalisme dan persepsi seseorang terhadap kebenaran. Dengan loyal kepada faksi tertentu, mengindikasikan adanya konflik loyalitas yang mendasar (Gallagher dalam Kovach, 2004: 20), yang menurut Eriyanto (2004) dikemudian hari dikatakan sebagai ideologi media.

Penelitian mengenai kinerja pasangan Presiden dan Wakil Presiden Joko Widodo dan Jusuf Kalla selama setahun pemerintahan sudah dilakukan oleh beberapa peneliti sebelumnya. Dimulai dari survei tingkat kepuasan masyarakat terhadap kinerja JokowiKalla menjelang setahun masa pemerintahan, yang diterbitkan oleh Indo Barometer, pada 8 Oktober 2015 bertajuk "Keberhasilan dan Kegagalan Setahun Pemerintahan Jokowi-JK,". Disebutkan bahwa sepanjang pemerintahan Jokowi-Kalla, telah terjadi penurunan tingkat kepuasan masyarakat atas kinerja pemerintahan Jokowi-Kalla dalam masa menjelang setahun pemerintahan mereka jika dibandingkan dengan 6 bulan yang lalu. (indobarometer.com/:: 2015/10/09 diakses: 18 Agustus 2016). Demikian juga dengan hasil survei Lembaga Survei Indonesia (LSI) yang dipublikasikan pada 2 Februari 2015. Bertajuk "Evaluasi Terhadap Kinerja 
100 Hari Pemerintahan Jokowi-JK" (www. 1si.or.id. Diakses 19 Agustus 2016).

Penelitian secara akademis terkait kinerja pemerintahan Jokowi-Kalla dilakukan sebelumnya oleh Lapalelo (2016) yang mengamati pembingkaian berita sosok Jokowi-Kalla sebagai Presiden dan Wakil Presiden melalui pemberitaan headline SKH Kompas dan Jawa Pos yang terbit sepanjang 19-21 Oktober 2015. Hal ini dikaitkan dengan afiliasi politik media, di mana dikatakan bahwa media massa tidak pernah lepas dari pengaruh politik dalam menentukan arah berita dan menentukan proses seleksi informasi (Nugroho, Eriyanto dan Surdiasis, 1999: 3). Lebih lanjut pembingkaian berita juga dikaitkan dengan arah politik media, karena tidak ada media massa yang tidak memiliki arah afiliasi politik tertentu atau yang tidak pernah terlibat dengan konglomerasi media (Lapalelo, 2016:12). Penelitian lainnya dilakukan oleh dalam membingkai berita 100 hari kerja JokowiJK melalui Program Berita Metro Hari ini (Febriani, 2016). Penelitian ini bertujuan untuk mengonfirmasi pembingkaian berita tajuk rencana 5 media massa di Indonesia dalam mengawal kinerja setahun pemerintahan Jokowi-Kalla.

\section{Metode Penelitian}

Penelitian ini menggunakan metode kuantitatif dan kualitatif. Metode kuantitatif digunakan untuk menganalisis teks yang akan dilanjutkan kemudian dengan konfirmasi pada level konteks melalui wawancara sumber. Sementara pendekatan kualitatif digunakan untuk menganalisis persepsi publik terhadap objek penelitian. Peneliti kuantitaif akan memperdalam penelitian dengan menggunakan metode analisis framing. Metode analisis framing sendiri memiliki beberapa pilihan model. Dimulai dari model Robert Entman, model Zhongdang Pan dan Gerald M. Kosicki, model Murray Edelman, dan model William A. Gamson.

Penelitian ini dianalisis dengan menggunakan analisis framing Entman. Entman melihat framing dalam dua dimensi besar: seleksi isu dan penekanan atau penonjolan aspek-aspek tertentu dari realitas. Seleksi isu berkaitan dengan pemilihan fakta. Dari realitas yang kompleks dan beragam, aspek mana yang diseleksi untuk ditampilkan. Dari proses ini selalu terkandung di dalamnya ada bagian berita yang dimasukkan, tetapi ada juga berita yang dikeluarkan. Tidak semua aspek atau bagian dari isu ditampilkan, di mana wartawan memilih aspek tertentu dari suatu isu.

Penelitian ini lebih menonjolkan isu kinerja Joko Widodo dan Jusuf Kalla yang tampil di halaman tajuk rencana di masingmasing media massa yang terbit secara nasional. Alasan pemilihan ke-5 media ini didasarkan pada coverage berita yang mencapai hingga pelosok Indonesia dan jumlah terbitan media yang relatif banyak dan menyebar. Berikut adalah tabel media massa beserta judul pada rubrik tajuk rencana yang terbit pada 20 Oktober 2015.

Tabel.1: Daftar Media dan Judul Tajuk Rencana

\begin{tabular}{ll}
\hline \multicolumn{1}{c}{ Media } & \multicolumn{1}{c}{ Judul Tajuk Rencana } \\
\hline Jawa Pos & Setahun Yang Terasa Lama \\
Kompas & Jokowi-Kalla, Setahun Kemudian \\
Koran Tempo & Setahun Kepemimpinan Jokowi \\
Media Indonesia & Menimbang Neraca Jokowi-JK \\
Republika & Setahun Masa Berbenah Usai \\
\hline
\end{tabular}




\section{Hasil Penelitian dan Pembahasan}

Media massa menjadi alat utama pemirsanya untuk belajar tentang masyarakat dan kultur lingkungannya. Jika ingin mengetahui dunia nyata dan membuktikan apa yang dibayangkan dan dipersepsikan, manusia dapat menemukannya melalui media massa. Artinya, selama pemirsa kontak dengan media, mereka akan belajar tentang dunia (dampak pada persepsi), belajar bersikap dan nilai $\square$ nilai orang (Hadi, 2007:89). Media cetak surat kabar yang memiliki jangkauan luas, terbit setiap hari, serentak, dan beritanya terdokumentasi, membuat media cetak terutama koran menjadi salah satu media massa yang cukup efektif menyebarkan informasi kepada publik.

Bingkai Jawa Pos: Setahun yang Terasa Lama

Tidak ada narasumber dalam tulisan ini, namun latar informasi cukup jelas mengenai banyaknya masalah yang dihadapi pasangan presiden dan wakil presiden yang baru dilantik, serta harapan pada kinerja keduanya ke depan. Jawa Pos menilai bahwa kinerja pemerintahan Joko Widodo dan Jusuf Kalla terasa lambat, sementara kondisi perekonomian di dunia menjadi potensi keterpurukan bagi Indonesia jika tidak segera mendapat perhatian. Jawa Pos menilai kegagalan ada setahun pertama pemerintahan Jokowi-Kalla justru diciptakan oleh presiden Joko Widodo itu sendiri.

Persoalan "warisan" dari pemerintah di masa lalu, kondisi perekonomian dunia internasional, ditambah desakan-desakan daripartaipengusungpasangan JokoWidodo dan JusufKalla, disinyalirmenjadikan ruang gerak dan percepatan kinerja pasangan ini mengalami perlambatan. Perlambatan ini ditunjukkan dengan pengentasan masalah korupsi Gubernur Sumut Gatot Pudjo Nugroho yang mengakibatkan kerugian negara senilai Rp2,2 miliar tidak segera ditangani, sementara selesai atau tidaknya masalah-malasah ini tergantung dari upaya penegakan yang dilakukan Joko Widodo sebagai kepala negara.

Beberapa kasus dianggap sebagai bukti jika pasangan Joko Widodo dan Jusuf Kalla kurang tegas, misalnya kemunculan nama Budi Gunawan sebagai bursa calon pemilihan Kapolri yang akan menggantikan Jendral Sutarman. Ada dugaan pemilihan Jokowi atas nama Budi Gunawan karena ada pengaruh dari Megawati Soekarniputri yang tidak lain adalah ketua umum dari partai yang mengusung Joko Widodo sebagai presiden, PDI Perjuangan. Akibatnya, pada awal pemerintahan Joko Widodo dan Jusuf Kalla mendapat tekanan besar dari anggota parlemen untuk melakukan revisi pada Undang-undang yang dirasa tidak masuk akal dan penting dilakukan, yaitu revisi UU KPK dan UU Penghapusan Pajak.

Hal ini menjadi sorotan Jawa Pos karena rakyat memiliki harapan besar pada pasangan Presiden dan Wakil Presiden ini. Di tangan pasangan inilah negara dan bangsa ini menjadi taruhannya. Maka harapannya, pasangan Jokowi-Kalla tidak mudah terbujuk untuk merealisasikan kebijakan-kebijakan yang dirasa tidak pro rakyat ataupun kebijakan-kebijakan yang tidak mendukung bagi upaya kesejahteraan rakyat. Selain tanggungjawab moral, rakyat juga dianggap cukup cerdas untuk melihat 
apakah satu kebijakan dirasa perlu untuk direalisasikan, sementara masih banyak kasus-kasus lain yang membutuhkan perhatian dan penanganan hukum segera.

Bingkai Kompas: Jokowi-Kalla, Setahun Kemudian

Kompas memuat kolom tajuk rencana ini dengan hanya pasangan Jokowi dan Kalla sebagai aktor utama dalam tulisan ini di mana digambarkan bagaimana pasangan Presiden dan Wakil Presiden ini menjadi harapan seluruh bangsa Indonesia dan pekerjaan rumah mereka sepanjang masa pemerintahannya 4 tahun kemudian. Pihak lain yang turut menjadi aktor dalam tulisan ini adalah anggota Kabinet Kerja, serta mesin birokrasi pada tingkat eselon satu dan eselon dua yang tidak lain adalah para pemimpin daerah dan ibukota provinsi. Peran mereka disebutkan sebagai pihak-pihak yang turut berkontribusi dalam mencatat rapot pemerintahan Jokowi-Kalla pada setahun pertama pemerintahannya.

Kompas memulai tulisannya dengan memori saat pasangan Joko Widodo dan Jusuf Kalla terpilih sebagai pasangan Presiden dan Wakil Presiden pada 14 Oktober 2014. Bagaimana respon media dan suasana saat pelantikan, menjadi gambaran betapa optimisme seluruh masyarakat melekat pada sosok keduanya. Bukan hanya masyarakat di Indonesia, masyarakat dunia juga seakan turut mengamini jika pasangan terpilih ini menjadi tumpuan harapan bagi bangsa dan negara. Simbolisasi peristiwa yang lekat dengan dukungan rakyat, menjadi gambaran jika pasangan ini menjadi sosok yang benar-benar diharapkan banyak pihak.
Namun selama setahun sejak keduanya dilantik, kondisi perekonomian dunia tidak mendukung. Krisis Eropa memberi dampak yang turut dirasakan seluruh rakyat Indonesia. Dampak krisis global juga yang turut menyumbang persoalanpersoalan ekonomi yang tidak mudah diatasi. Akibatnya, optimisme yang sejak awal disanjung tinggi, pada setahun pertama pemerintahan Jokowi-Kalla justru menipis.

Dalam tulisannya Kompas menyatakan bahwa keluhan banyak dirasakan pada sektor ekonomi, ditandai dengan pelemahan rupiah, fluktuasi harga, dan pertumbuhan ekonomi yang tidak sesuai target. Namun tidak sepenuhnya ini merupakan "kesalahan" Jokowi-Kalla, karena ternyata pemerintahlah yang menurut Kompas gagap merespon kondisi perekonomian dalam negeri. Pemerintah di sini digambarkan sebagai anggota kabinet bahkan sampai perangkat di daerah yang tidak sejalan dengan kebijakan Presiden. Maka, selama optimisme masih dimiliki pasangan Presiden dan Wakil Presiden yang baru terpilih setahun lalu, maka ada harapan jika tahun-tahun berikutnya pasangan ini akan lebih maksimal kinerjanya. Mulai dari menyamakan langkah dalam hal visi dan misi penyejahteraan rakyat, mesin birokrasi yang lebih baik dan bekerja aktif, serta pengendalian kebijakan sampai ke level daerah agar sejalan dengan harapan dan keinginan pemerintah pusat.

Bingkai Koran Tempo: Setahun Kepemimpinan Jokowi

Pada tajuk rencana Koran Tempo menyertakan beberapa nama sebagai bagian 
dari narasi rapor setahun kepemimpinan Jokowi dan Jusuf Kalla. Muncul nama Menteri Koordinator Kemaritiman Rizal Ramli, Menteri BUMN Rini Soemarno, Menteri Energi Sudirman Said, Menteri Perhubungan Igansius Jonan, juga muncul nama yang kala itu digadang-gadang sebagai calon Kapolri Komjen Budi Gunawan. Sorotan kinerja Jokowi dan Jusuf Kalla juga disangkut pautkan dengan nama-nama di atas yang merupakan bagian dari Kabinet Kerja pemerintahan Joko Widodo dan Jusuf Kalla. Beberapa catatan mengenai kinerja mereka juga diangkat sebagai salah satu faktor penentu rapor kinerja setahun pemerintahan JokowiKalla, terutama peranan Jokowi sebagai kepala negara.

Pada halaman tajuk rencana Koran Tempo, dikatakan bahwa rapor merah pada setahun kepemimpinan JokowiKalla dipengaruhi utamanya pada sistem manajemen pemerintahan mereka. Bahkan dikatakan bahwa sepanjang setahun kepemimpinannya, Jokowi memiliki visi yang berbeda dengan anggota kabinetnya dalam mengemban tugas. Dimulai dari adu argumen di kalangan menteri menjadi bukti tidak adanya koordinasi antar menteri terkait apa yang menjadi visi Presiden, atau ketidakmampuan Jokowi mengendalikan orang-orang yang turut dalam Kabinet Kerja-nya. Lebih jauh dikatakan bahwa adanya perbedaan visi ini dikarenakan Jokowi salah memilih orang-orang yang menjadi bagian dari Kabinet Kerja-nya. Kesalahan dalam memilih orang juga mendapat sorotan saat Jokowi memilih
Komjen Budi Gunawan sebagai calon Kapolri, padahal mantan ajudan Megawati Soekarnoputri ini disinyalir memiliki rekening dengan jumlah tidak wajar. Artinya, Budi Gunawan tidaklah tepat dipilih sebagai pemimpin lembaga penegak hukum jika dirinya sendiri terindikasi melakukan praktik-praktik pelanggaran hukum.

Selain itu kondisi perekonomian global juga turut berkontribusi pada penilaian publik atas kinerja Jokowi-Kalla, meskipun diakui jika kondisi ini turut berpengaruh pada negara-negara lain di kawasan Asia. Harga kebutuhan pokok yang makin melambung tinggi, nilai tukar rupiah yang anjlok, sudah kadung dikait-kaitkan dengan kinerja Jokowi-Kalla, akibatnya masyarakat menjadi tidak lebih puas pada kepemimpinan Jokowi-Kalla.

Kaitannya dengan rekomendasi dan solusi yang ditawarkan, Koran Tempo memberi masukan jika ada baiknya Jokowi dan Kalla memperbaiki kinerja mereka dalam hal sistem pemerintahan pada periode-periode berikutnya. Selain itu kesolidan tim kerja Jokowi-Kalla juga menjadi kuncinya.

Bingkai Media Indonesia: Menimbang Neraca Jokowi-JK

Pada tajuk rencana ini tidak ada pihak lain yang dijadikan focus pada uraian naskah, hanya Jokowi dan Kalla yang menjadi inti perbincangan. Namun bagaimana peran Jokowi-Kalla dalam berbagai kasus yang turut berperan dalam rapor kinerja setahun Jokowi-Kalla, antara lain ancaman penyerberangan antara Koalisi 
Merah Putih dan Koalisi Indonesia Hebat, pembangunan tol Cipali dan tol Kalimantan Timur-Kalimantan Barat, pemangkasan dwelling time, dan perintah pencabutan izin pembakaran lahan. Ada beberapa kasus lain, masing-masing diklasifikasi sebagai bagian dari kelemahan pemerintahan Jokowi-Kalla, namun beberapa kasus dijadikan sebagai bukti prestasi kinerja Jokowi-Kalla selama setahun pemerintahan.

Dalam paparannya, Media Indonesia terkesan tidak memberikan banyak tekanan pada rapor pemerintahan Jokowi-Kalla selama setahun pertama. Dalam artikel ini justru saat publik terlalu menuntut banyak hal pada pemerintahan dua populis ini, dinilai kurang bijak. Penilaian harus proporsional, karena ada sejumlah prestasi yang tidak dilakukan pada masa setahun pemerintahan sebelumnya dilakukan dengan begitu baik. Penuntasan pembangunan tol Cipali dan tol Kalimantan Timur-Kalimantan Barat, pemangkasan dwelling time, pencabutan izin perusahaan pembakar lahan, eksekusi mati bandar narkoba, grasi sejumlah tahanan politik, penindakan kelompok intoleran, kebijakan penenggalaman kapal pencuri ikan, keberhasilan menyelenggarakan peringatan $60^{\text {th }}$ KAA, serta pengalihan subsidi bahan bakar minyak ke bahan bakar yang lebih produktif, merupakan sejumlah prestasi yang disebut oleh Media Indonesia, dan tidak ada dalam tajuk rencana media massa lain.

Selain itu Media Indonesia menegaskan jika pemerintahan Jokowi-Kalla mewarisi persoalan pada pemerintahan presiden sebelumnya yang menurutnya masih belum selesai. Bayang-bayang perpecahan kubu Koalisi Indonesia Hebat dan Koalisi Merah Putih, turut membuat pemerintahannya terasa berat, ditambah krisis ekonomi global yang membuat target pertumbuhan tidak tercapai. Meski demikian beberapa persoalan tersebut menurut Media Indonesia jika tidak segera diselesaikan dengan cepat dan cermat, akan membuat kepercayaan publik pada kinerja 4 tahun berikutnya akan terancam. Maka catatan Media Indonesia, dua pasangan populis ini harus segera menuntaskan persoalan Indonesia sesegera mungkin.

Bingkai Republika: Setahun Masa Berbenah Usai

Selain Jokowi-Kalla yang menjadi aktor utama dalam pembahasan ini, Republika hanya menyertakan satu nama dalam tulisan ini. Dia adalah Sukardi Rinakit yang belum lama ditunjuk sebagai staf khusus Menteri Sekertaris Negara Pratikno bidang politik dan pers. Sukardi Rinakit yang oleh Republika mendapat sebutan Cak Kardi, merupakan salah satu tim sukses Jokowi-Kalla saat bertarung dalam ajang Pilpres 2014 lalu. Petikan Cak Kardi dicuplik sebagai penegasan dari uraian artikel terkait kinerja JokowiKalla selama setahun pemerintahan yang diuraikan dalam naskah tajuk rencana.

Berdasarkan paparan Harian Republika berjudul Setahun Masa Berbenah Usai, dalam catatan tajuk rencana Republika dikatakan bahwa setahun masa kepemimpinan Jokowi dan Kalla banyak pihak merasa senang, namun juga sedih, gemas, marah, kecewa, karena merasa bahwa kinerja keduanya tidak 
segera memberi hasil yang seperti diharapkan. Dimulai dengan pernyataan bahwa perjalanan pemerintahan Jokowi dan Kalla tidak mulus, ditunjukkan dengan adanya banyak perbedaan pendapat antar pembantu presiden (Menteri). Akibatnya, jalan pemerintahan tersendat, bahkan dirasa kebijakan Jokowi dan Kalla berlawanan dengan pemerintahan sebelumnya. Artinya, ada kebijakan-kebijakan yang sejatinya tinggal dijalankan, namun akhirnya tersendat karena adanya perbedaan pendapat dengan masa pemerintahan JokowiKalla.

Republika juga menyoroti banyaknya konflik iternal dalam tubuh pemerintahan Jokowi-Kalla, ditunjukkan dengan baku sikut anggota DPR, polemik pemilihan Kapolri, kontroversi pimpinan KPK, saling sindir dan tuding kalangan menteri, bahkan tidak sinkronnya pendapat dan pandangan antara presiden dan wakil presidennya. Akibatnya, tidak terasa pemerintahan Jokowi-Kalla justru lebih banyak menorehkan kinerja yang negatif dibandingkan dengan prestasi positif yang dihasilkan.

Republika juga mengutip pernyataan salah satu staf khusus Kementrian Sekertaris Negara yang baru dilantik, Sukardi Rinakit, yang mengatakan bahwa apa yang dilakukan pemerintahan JokowiKalla semata-mata adalah upaya untuk menata pondai pemerintahan yang lebih baik, maka barangkali kinerja pemerintahan belum begitu maksimal, sementara rakyat berharap kinerja Jokowi-Kalla dapat berjalan langsung cepat dan instant, menyelesaikan semua persoalan dalam setahun pemerintahan ini. Maka, Republika meminta publik menilai kinerja setahun pemerintahan lebih obyektif dan adil menilai kinerja pemerintahan karena masih ada 4 tahun sisa pemerintahan JokowiKalla. Selain itu mengontrol dan mengkritis arah kerja Jokowi-Kalla yang harus sejalan dengan visi dan misi serta program yang telah dijanjikan, yaitu Nawacita. Jika ada kinerja pejabat pemerintahan yang tidak sesuai, rakyat perlu mengingatkan.

Analisis Bingkai Tajuk Rencana 5 Media Massa

Berdasarkan analisis pada level konteks di atas, dapat disimpulkan bahwa kelima media massa di Indonesia (Jawa Pos, Kompas, Media Indonesia, Koran Tempo, dan Republika) memiliki kesamaan dalam pandangan mereka melihat evaluasi satu tahun pemerintahan Jokowi-Kalla.

Pada pendefinisian masalah, kelima media setuju jika pada satu tahun pemerintahan Jokowi-Kalla keduanya menghadapi beberapa persoalan yang cukup krusial sehingga membuat kinerja keduanya dianggap tidak maksimal, tidak sesuai dengan harapan publik di awal keterpilihan mereka yang sangat fenomenal. Persoalan tersebut dapat diidentifikasi sebagai persoalan karena adanya faktor eksternal dan internal.

Faktor eksternal yang dimaksud adalah kondisi perekonomian dunia yang sedang tidak stabil dan memberi dampak bagi kondisi perekonomian dalam negeri. Sejumlah media massa mengamati bahwa gejolak ekonomi dunia yang tengah terjadi sepanjang 2015 turut menekan laju 
perekonomian Indonesia sehingga membuat perlambatan. Hal ini disebabkan kenaikan tingkat suku bunga AS dan melemahnya nilai tukar Rupiah terhadap Dollar yang menyebabkan perlambatan ekonomi. Faktor eksternal ini dianggap sebagai situasi yang menguntungkan keduanya dalam memulai pemerintahan karena membuat persoalan tidak bisa begitu saja selesai dalam waktu cepat. Bahkan beberapa media mengatakan pengaruh eksternal ini membuat persoalan di negara ini relatif tidak mudah diselesaikan, bahkan sulit dan menambah bebean berat bagi Jokowi-Kalla di satu tahun pemerintahan mereka. Apalagi beberapa persoalan dikatakan sebagai warisan dari pemerintahan sebelumnya, membuat tahun pertama pemerintahan Jokowi-Kalla ini memiliki semakin banyak pekerjaan rumah.

Faktor internal yang dimaksudkan sebagai akar persoalan kurang maksimalnya kinerja Jokowi-Kalla dalam tahun pertama pemerintahan ini adalah karena tuntutan dari rakyat Indonesia yang ingin keduanya segera menyelesaikan masalah, meskipun hal tersebut dirasa mustahil. Maka, ada saran bagi rakyat Indonesia untuk tidak langsung menilai jika pemerintahan mereka gagal di tahun pertama ini, dan memberi kesempatan bagi keduanya untuk menyelesaikan masalah di tahun-tahun berikutnya.

Hal yang turut serta berkontribusi sebagai akar persoalan di satu tahun pemerintahan Jokowi-Kalla adalah persoalan carut marutnya sistem pemerintahan yang dibentuk Jokowi-Kalla melalui
Kabinet Kerja. Hal ini disebutkan oleh kelima media sebagai persoalan yang menjadi kontribusi utama masalah, di mana dikatakan Jokowi-Kalla dinilai salah memilih orang-orang yang duduk di jajaran kursi Kabinet Kerja, dibuktikan dengan kegagapan mereka merespon kondisi perekonomian dunia. Selain itu perpecahan di antara orang-orang dalam Kabinet kerja, ditangkap oleh publik sebagai bentuk kegagalan Jokowi-Kalla dalam memilih orang-orang yang bekerja di bawah kabinetnya sehingga membuat jalannya pemerintahan tersendat, dan hanya menampilkan drama perpecahan dalam internal pemerintahan Jokowi-Kalla. Meski demikian kelima media ini melihat masih ada kesempatan bagi pemerintahan Jokowi-Kalla agar dapat menjalankan tugas dan fungsinya sebagai pemimpin negara secara lebih baik di masa yang akan datang.

Menurut kelima media ini, Jokowi sebagai Kepala Negara dan Jusuf Kalla sebagai Wakil Presiden masih mendapatkan kepercayaan dari rakyat Indonesia yang memilihnya sebgaai pemimpin bangsa, pada periode 2014-2019. Maka, jika pada tahun pertama pemerintahan mereka masih ada masalah, kesempatan masih diberikan pada empat tahun sisa pemerintahan mereka di periode ini. Sisa empat tahun pemerintahan ini justru menjadi penentu bagi keduanya untuk dapat mengembalikan kepercayaan publik yang sudah memilih mereka, dan membuka peluang bagi keduanya untuk memiliki predikat sebagai Presiden dan Wakil Presiden yang sukses memimpin bangsa. 
Sementara itu diharapkan rakyat Indonesia tidak terlalu terburu-buru menuntut banyak pada kinerja keduanya, dan menganggap bahwa satu tahun kinerja mereka ini sebagai upaya "pemanasan" dan pemetaan masalah. Kepercayaan publik pada kemampuan keduanya dalam menyelesaikan persoalan internal, menjadi salah satu indikator keberhasilan keduanya dalam periode pemerintahan mereka kali ini, karena bagaimanapun juga Jokowi dan Kalla adalah dua orang yang sudah terpilih sebagai Presiden dan Wakil Presiden terpilih pada periode pemerintahan 2014-2019.

Beberapa masukan yang disampaikan kelima media massa ini adalah langkahlangkah praktis yang disarankan bagi pemerintahan Jokowi-Kalla. Utamanya adalah untuk bersikap tegas pada person-person yang sejalan dengan arah dan tujuan keduanya sebagai Presiden dan Wakil Presiden, juga mereka-mereka yang dirasa tidak memajukan kebijakan-kebijakan yang pro rakyat.

Langkah awal dapat dimulai dengan menegaskan kesamaan langkah person yang ada di bawah susunan Kabinet Kerja. Jika perlu, ada perbaikan untuk mencari orangorang yang sejalan. Selain itu diharapkan Jokowi dan Kalla dapat menolak tegas kebijakan yang tidak menjadi kebutuhan mendasar rakyat, dan menyusun strategi yang lebih pro rakyat.

Level Konteks dalam Pembingkaian Tajuk Rencana 5 Media Massa di Indonesia

Dalam memroduksi informasi menjadi sebuah berita kepada khalayaknya, media massa memiliki struktur hirarki yang melandasi keterpilihan angle atau isi

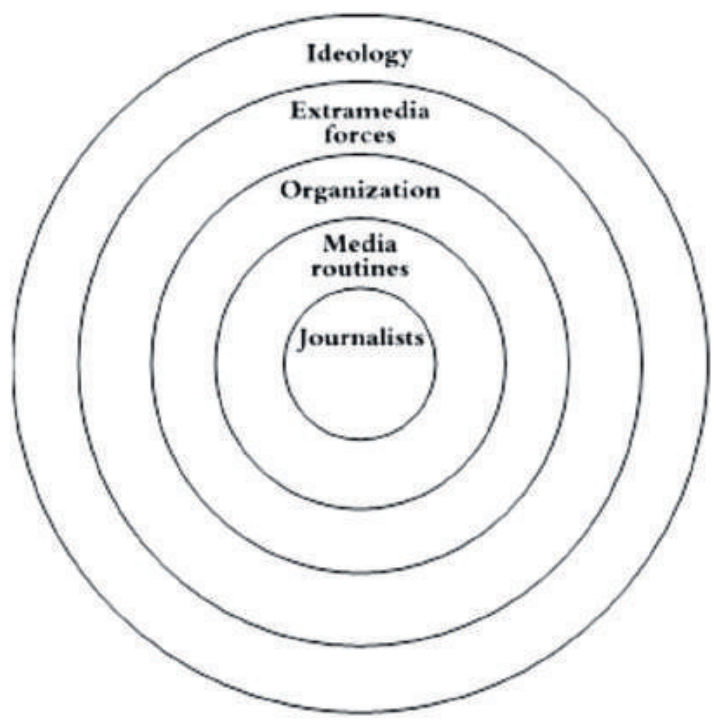

Gambar 1. Hierarchy of Influence Model Shoemaker \& Reese

dalam berita (Sobur, 2006:138). Artinya, isi berita dalam media tidak lepas dari pengaruh-pengaruh yang melatarbelakangi pembingkaian berita sebelum akhirnya disajikan kepada khalayak. Oleh karena itu satu isu dapat menjadi berbeda dalam meramu isu menjadi berita, tergantung bagaimana kuatnya pengaruh isi berita. Hal ini seperti digambarkan Pamela Shoemaker dan Stephen D. Reese (2014) dalam Model Hierarchy of Influence.

Berdasarkan uraian di atas, maka selain menghasilkan analisis pada level teks berita, maka sebagai bentuk konfirmasi maupun klarifikasi pada isi berita dapat dilakukan dengan menganalisis level konteks berita, atau hal-hal yang turut mempengaruhi isi berita. Analisis level konteks dilakukan dengan metode wawancara, orang-orang dalam ruang redaksi media. Namun dikarenakan kendala yang dapat berupa kesibukan awak redaksi, maupun kesulitan dalam hal penjadwalan, wawancara hanya dapat dilakukan kepada 2 (dua) 
awak redaksi dari dua media massa, yaitu Kompas dan Koran Tempo, sementara 3 (tiga) yang lain (Jawa Pos, Media Indonesia, dan Republika) akan dilihat dari pengaruh rutinitas media dan organisasi media.

Wawancara wakil redaksi Kompas dilakukan pada 30 April 2016. Dalam wawancara tersebut, dikatakan bahwa kaitannya dengan setahun pemerintahan Jokowi-Kalla, Kompas memberikan perhatian besar pada pemberitaan kinerja Jokowi-Kalla di medianya yang terbit pada 20 Oktober 2015. Sejak pelantikan Joko Widodo dan Jusuf Kalla sebagai Presiden dan Wakil Presiden, Kompas selalu mengawal keduanya dalam menjalankan roda pemerintahan. Upaya ini dilakukan semata karena Kompas sebagai media nasional yang cukup berpengaruh di Indonesia, berharap keduanya benar-benar mengemban amanat rakyat sebagai pemimpin negara yang dapat menyelesaikan persoalanpersoalan bangsa.

Naskah Tajuk Rencana disusun sesuai dengan kesepakatan dalam ruang rapat redaksi. Naskah Tajuk Rencana merupakan tugas yang diberikan secara bergiliran bagi para redaktur pelaksana di Kompas untuk menyusun naskahnya, sebelum kemudian disepakati masuk dalam kolom koran. Maka, dapat dikatakan bahwa secara teknis penyusunan naskah Tajuk Rencana merupakan bagian dari rutinitas media, namun juga tidak lepas dari upaya pengaruh organisasi media untuk mengawal isi naskah.

Dikatakan bahwa Kompas selalu berupaya menjaga netralitas dalam mengawal berita pemerintahan Joko
Widodo dan Jusuf Kalla. Hal ini sejalan dengan fungsi media. Jika ada awak redaksi yang menunjukkan afiliasinya pada satu aliansi politik misalnya, tidak segan-segan pimpinan redaksi memberikan teguran maupun sanksi bagi yang bersangkutan.

Menanggapi tentang isi Tajuk Rencana yang seakan memberikan kritik pada sistem pemerintahannya, Kompas melihat kelemahan pemerintahan Jokowi-Kalla itu ada pada orang-orang yang diharapkan dapat bekerjasama dengannya, namun terkadang memiliki cara dan visi yang berbeda.

Senada dengan Kompas, perwakilan redaksi Koran Tempo juga mengemukakan bahwa kritik redaksi Tempo berangkat dari pendapat di ruang redaksi bahwa sosok Joko Widodo layak menjadi Presiden, namun perlu didukung oleh orang-orang yang benar-benar mau bekerjasama dengannya membangun bangsa.

Maka, penilaian itu juga tampak dalam petikam Tajuk Rencana Koran Tempo bahwa Joko Widodo dianggap tidak dapat mengendalikan menteri-menterinya, bahkan salah memilih orang di bawah kepemimpinannya. Selain itu, ada beberapa hal dari kepemimpinan Jokowi belum memiliki pengalaman dan pemahaman dalam menyelesaikan berbagai persoalan, sehingga dirasa perlu memilih orang-orang yang sepaham dan sejalan dengan visi dan misinya sebagai pemimpin negara. Jika langkah ini tetap dilanjutkan, maka persoalan ketidak solidan pemerintahan Jokowi-Kalla akan terus berulang dan menjadi persoalan internal yang berlarut-larut. 
Jawa Pos, dalam terbitan 20 Oktober 2015 yang menjadi momentum evaluasi setahun pemerintahan Jokowi-Kalla tidak memberikan porsi yang cukup mencolok. Tidak muncul pemberitaan lain kaitannya dengan evaluasi kinerja Joko Widodo dan Jusuf Kalla yang tepat pada 20 Oktober 2015, hanya artikel dalam Opini yang ditulis oleh wartawan Jawa Pos dan Tajuk Rencana. Sebagai sebuah perusahaan media, grup Jawa Pos pimpinan Dahlan Iskan ini tidak menunjukkan afiliasi politik mana pun, maka dapat dikatakan pengaruh organisasi media lebih mengedepankan pada penilaian yang terang-terangan. Apalagi sebagai media yang berasal dari Jawa Timur, rutinitas media seakan menunjukkan sikap terang-terangan dalam merumuskan penilaian pada kinerja Joko Widodo dan Jusuf Kalla yang menurut mereka belum menunjukkan prestasi di setahun pertama pemerintahan mereka. Misalnya saja ketika Jawa Pos menilai selama setahun pertama pemerintahan Joko Widodo dan Jusuf Kalla, terjadi perlambatan ekonomi dan ide untuk menghidupkan kembali pasal penghinaan presiden di KUHP. Apalagi menurut Jawa Pos, Joko Widodo yang pada awalnya "galak", belakangan kemudian tidak menunjukkan ketegasannya dalam memerintah sepanjang setahun ini.

Menjelang Pemilu 2014, Winter (2014) mengatakan bahwa Jawa Pos bersama-sama dengan Viva News Groupmenunjukkanafiliasi politiknya pada sosok Aburizal Bakrie. Saat di kemudian hari nama Aburizal Bakrie tidak cukup kuat masuk dalam bursa calon presiden, Partai Golkar di bawah asuhan Aburizal Bakrie menunjukkan keberpihakannya pada calon presiden dari kubu Koalisi Merah Putih yang mengusung calon Prabowo Subianto. Maka dengan demikian dapat disimpulkan "suara-suara" yang muncul dalam artikel Tajuk Rencana juga sebagai bagian dari warisan perpecahan antara Koalisi Merah Putih pimpinan Prabowo Subianto dan Koalis Indonesia Hebat pimpinan Joko Widodo. Tidak heran juga jika dalam artikel tersebut juga muncul pendapat bahwa akar dari persoalan ini ada pada sosok Joko Widodo dan Jusuf Kalla itu sendiri. Ditambah dengan situasi perekonomian global yang sedang tidak stabil, menjadikan kinerja Jokowi-Kalla semakin tidak maksimal karena tidak adanya kebijakan yang segera diwujudkan sehingga menimbulkan perlambatan ekonomi.

Bertolak belakang dengan Jawa Pos, Media Indonesia yang berada di bawah bendera Media Group pimpinan Surya Paloh, sejak awal kampanye pemilihan umum presiden 2014 sudah menyatakan dukungannya kepada pasangan Joko Widodo dan Jusuf Kalla melalui Koalisi Indonesia Hebat. Bahkan dalam beberapa kali kampanye di daerah, Surya Paloh mendampingi Jusuf Kalla yang berkampanye untuk Pemilu 2014. Fakta tersebut dapat dikatakan sebagai bentuk pengaruh organisasi media yang berafiliasi dengan sosok utama dalam pembahasan Tajuk Rencana, yaitu pasangan Presiden dan Wakil Presiden Joko Widodo dan Jusuf Kalla, dalam evaluasi setahun pemerintahan mereka. Tidak heran jika dalam artikel Tajuk Rencana, Media Indonesia cenderung mendorong agar penilaian pada kinerja Joko Widodo dan Jusuf Kalla tidak langsung menjadi raport buruk kineja Jokowi-Kalla. 
Lebih khusus dalam terbitan tertanggal 20 Oktober 2015, Media Indonesia memberikan porsi yang cukup besar dalam evaluasi setahun kepemimpinan Joko Widodo dan Jusuf Kalla. Utamanya adanya artikel dalam Headline yang berjudul: Pekerjaan Besar Butuh Waktu, disertai dengan tulisan tangan Joko Widodo lengkap dengan tandatangan. Maka, dapat dikatakan bahwa rutinitas media dan organisasi media menunjukkan dukungan serta afiliasinya dalam mengajak pembaca Media Indonesia agar tidak terlalu terburu-buru memberikan penilain pada kinerja Jokowi-Kalla di setahun pemerintahan mereka. Utamanya menurut Media Indonesia, ada hal-hal yang menjadi persoalan, dan itu di luar jangkauan Jokowi-Kalla sebagai Presiden dan Wakil Presiden, yaitu warisan persoalan di pemerintahan sebelumnya serta perpecahan akibat bayang-bayang Pemilu 2014 lalu. Meski demikian evaluasi tetap ditunjukkan dengan ajakan agar ke depan langkah kebijakan Joko Widodo dan Jusuf Kalla lebih terarah dan segera menyelesaikan persoalan bangsa.

Terakhir adalah Republika yang merupakan bagian dari kelompok Grup Mahaka Media, milik pengusaha Erick Thohir. Menurut Winters (2014), pada perhelatan Pemilu 2009 sampai dengan 2014, sejumlah media menunjukkan partisipasinya dalam sosok calon presiden yang diistilahkan sebagai pendukung tidak resmi (2014:.28). Erick Thohir yang menjabat sebagai Direktur Viva News Group tentu menunjukkan dukungannya pada Koalisi Merah Putih yang menjadi lawan politik Jokowi Widodo dengan
Kolalisi Indonesia Hebat. Maka, dalam artikel Tajuk Rencana, dikatakan bahwa persoalan utama dalam melihat evaluasi kinerja JokowiKalla dalam setahun pemerintahan adalah tidak mulusnya roda pemerintahan JokowiKalla seperti yang diharapkan.

Republika juga menyoroti kisruh dalam internal Kabinet Kerja yang melibatkan menteri-menteri yang saling beradu argumen dan pendapat terkait dengan satu atau dua kebijakan. Termasuk saling sikut anggota DPR. Carut marut ini yang menurut Republika sebagai salah satu kegagalan pemerintahan Jokowi-Kalla dalam setahun pemerintahannya. Ditambah lagi perbedaan pandangan dan kebijakan antara pemerintahan Jokowi-Kalla dengan kebijakan pemerintahan lalu, membuat persoalan yang dihadapi menurut Republika tidak segera dapat diselesaikan.

Kericuhan inilah yang menurut Republika makin menebal, dan menutupi beberapa prestasi yang sejatinya sudah diraih dalam setahun pemerintahan Jokowi-Kalla. Meski demikian Republika berharap ada gebrakan baru dalam pemerintahan JokowiKalla ke depan, dan memberi kelonggaran waktu dalam menilai kinerja keduanya dalam empat tahun sisa pemerintahan mereka pada periode ini, sekaligus mengajak rakyat untuk turut mengawal pemerintahan ke depan.

\section{Simpulan}

Dari hasil analisis dan pembahasan di atas, dapat disimpulkan beberapa hal dari hasil penelitian dengan judul Evaluasi 1 Tahun Pemerintahan Kabiner Kerja Jokowi-JK di 5 media massa di Indonesia yang dianalisis dengan menggunakan 
metode analisis framing Robert Entman. Beberapa simpulan dalam penelitian ini didapatkan beberapa poin, sebagai berikut:

1. Jawa Pos dalam analisis teks Tajuk Rencananya dengan judul Setahun yang Terasa Lama menyoroti kinerja JokowiKalla berasal dari persoalan utama dimana pasangan ini bekerja sangat lambat dalam menyelesaikan masalah bangsa karena adanya beberapa kendala, baik itu kendala warisan masalah dari pemerintahan sebelumnya, juga karena dipengaruhi kisruh internal Kabinet Kerja yang menghasilkan kebijakankebijakan yang tidak sesuai dengan kebutuhan rakyat. Hal ini dipengaruhi oleh afiliasi Jawa Pos pada Pemilu 2014 yang menunjukkan keberpihakannya pada Koalisi Merah Putih yang notabene adalah lawan politik Joko Widodo yang mengusung Koalisi Indonesia Hebat.

2. Kompas dalam teks Tajuk Rencana-nya yang berjudul Jokowi-Kalla, Setahun Kemudianmenyorotturunnyapopularitas pasangan ini, jika dibandingkan dengan momentum keterpilihan mereka saat menjadi Presiden dan Wakil Presiden periode 2014-2019. Kompas menyorot sumbangsih persoalan ini ada pada situasi global yang sedang tidak stabil, ditambah dengan sistem manajemen JokowiKalla yang tidak dapat dikendalikan pasangan ini sebagai pemimpin negara. Berdasarkan wawancara dengan wakil redaksi Harian Kompas, penyusunan naskah dalam Tajuk Rencana dipengaruhi oleh fungsi Kompas yang akan bertindak sebagai media pengawas pada kinerja pemerintahan JokowiKalla. Maka, meski tidak membingkai isu pemerintahan Jokowi-Kalla dengan sangat tajam, Kompas berharap ke depan pemerintahan ini akan berjalan lebih baik dan terarah, utamanya dengan memberi menempatkan orang-orang yang sejalan dan sevisi dengan JokowiKalla sebagai pemimpin negara.

3. Koran Tempo dalam membingkai analisisnya sebagai bagian dari evaluasi kinerja Jokowi-Kalla melalui Tajuk Rencana dengan judul Setahun Kepemimpinan Jokowi sangat tegas, ditunjukkan dengan lemahnya kemampuan keduanya mengoordinasi kabinet yang mengakibatkan beberapa menteri justru saling beradu argumen dan pendapat, maka Koran Tempo berharap pemerintahan ini akan berjalan lebih solid. Hal ini seperti disampaikan oleh perwakilan redaksi yang mengatakan bahwa diakui jika pasangan Joko Widodo dan Jusuf Kalla memiliki visi dan misi yang baik, namun saat itu diakui memilih orang-orang yang salah.

4. Media Indonesia membingkai isi Tajuk Rencana-nya dengan judul Menimbang Neraca Jokowi-JK menegaskan belum saatnya jika public menilai kinerja Jokowi-Kalla di tahun pertama dengan negatif. Selain terlalu cepat, banyak persoalan yang merupakan warisan dari pemerintahan sebelumnya, juga pengaruh situasi eksternal yang tidak bisa diselesaikan Jokowi-Kalla dalam waktu cepat. Hal ini dipengaruhi oleh rutinitas media dan organisasi media, 
dimana Media Indonesia yang berada di bawah manajemen Media Group milik Surya Paloh sudah menunjukkan dukungan pada pasangan Joko Widodo sejak awal kampanye mereka sebagai calon presiden dan wakil presiden.

5. Republika dalam Tajuk Rencana-nya berjudul Setahun Masa Berbenah Usai membingkai evaluasi ini dengan sangat tajam, salah satunya kebijakan yang bertolak belakang dengan kebijakan pemerintah sebelumnya sehingga membuat persoalan bangsa tidak bisa langsung diselesaikan. Belum lagi persoalan internal Kabinet Kerja yang menurut Republika menutup beberapa prestasi yang sebenarnya sudah ditorehkan pasangan Joko Widodo. Hal ini dipengaruhi dari afiliasi politik Republika yang berada di bawah payung Mahaka Group milik Erick Thohir yang yang tidak lain merupakan Direktur Viva News Group. Pada awal Pemilu 2014, Viva News Group menunjukkan keberpihakannya pada Koalisi Merah Putih, lawan politik Jokowi-Kalla yang berada di kubu Koalisi Indonesia Hebat.

\section{Daftar Pustaka}

Ardianto, Komala dan Karlina. (2009). Komunikasi Massa Suatu Pengantar. Bandung: Simbiosa Rekatama Media.

Cangara, Hafied. (2009). Pengantar Ilmu Komunikasi. Jakarta: PT Raja Grafindo Persada

Eriyanto. 2004. Analisis Framing Konstruksi, Ideologi, Dan Politik Media. Yogyakarta: LKiS.
Febriani, N. K. N., Cahyani, D. Y., \& Gelgel, N. M. R. A. (2016). Pembingkaian Berita Seratus Hari Kerja Jokowi-JK (Analisis Framing Program Berita di Metro Hari Ini). E-Jurnal Medium, 1(2).

Khairani, Annisa. (2012). Pembingkaian Radikalisme pada Berita di Televisi Berita Nasional dalam Perspektif Imparsialitas. Skripsi. Universitas Indonesia.

Kovach. Bill dan Thomas Rosentiel. (2004). Elemen-Elemen Jurnalisme: Apa yang Seharusnya Diketahui Wartawan dan yang Diharapkan Publik. Jakarta: Institut Studi Arus Informasi

Lapalelo, P. A. (2016). Bingkai sosok Jokowi sebagai Presiden dalam pemberitaan setahun pemerintahan pasangan Presiden Joko Widodo-Jusuf Kalla di Headline SKH Jawa Pos dan Kompas edisi 1921 Oktober 2015 (Doctoral dissertation, Widya Mandala Catholic University Surabaya)

McQuail, Denis. (2010). McQuail's Mass Communication Theory 6th edition. London: Sage Publication, Ltd.

Nugroho, Bimo., Eriyanto., dan Surdiasis. (1999). Politik Media Mengenai Berita, Jakarta: ISAI

Shoemaker, Pamela. J., and Reese, Stephen. D. (2014) ( $3^{\text {rd }}$ edition). Mediating the Message in the 21th Century: A Media Sociology Perspective. New York: Routledge

Siregar, Ashadi. (1997). Bagaimana Meliput dan Menulis Berita untuk Media Massa. Yogyakarta: Kanisius.

Sobur, Alex. (2006). Analisis Teks Media, Bandung: Remaja Rosdakarya

Winters, J. (2014). Oligarchy and Democracy in Indonesia. In Pepinsky, Thomas. Beyond Oligarchy. Ithaca. Cornell University Press. 


\section{Internet}

http://ww w. indobarometer.com/ http://www.1si.or.id/riset/437/Rilis-LSIpublish/?read=analisa/1607/Survei:Masyarakat-yang-Puas-Kinerja-JokowiEvaluasi-100Hari-Kinerja-PemerintahanJokowi-JK. Diakses 19 Agustus 2016 JK-Kurang-dari-60-Persen. Diakses 19 Agusus 2016 